\title{
DIDACTICAL DESIGN RESEARCH BASED REFLECTION PRACTICE IN TEACHER PROFESSIONAL DEVELOPMENT
}

\author{
Vici Suciawati ${ }^{1}$, Sudianto $^{2}$, Mohamad Gilar Jatisunda ${ }^{3}$, Iik Nurhikmayati ${ }^{4}$ \\ ${ }^{1,2,3,4}$ Department Mathematics Education, Universitas Majalengka, \\ Jl. Kh. Abdul Halim, Indonesia \\ ${ }^{1}$ vicisuciawati@unma.ac.id, 22sudianto@unma.ac.id, ${ }^{3}$ g.jatisunda@unma.ac.id, \\ ${ }^{4}$ ik.nurhikmayati@unma.ac.id
}

\begin{abstract}
Reflection practice is a form of teacher professional development activity that has become the focus of study, research, and discussion in several scientific forums. The practice of reflection used so far is lesson study and educational action research. Didactical design research is one form of educational design research. DDR for mathematics teachers has been widely developing in Indonesia, both at the elementary, junior high, and high school levels. This service program begins with an introduction to Didactical Design Research. Form and its characteristics of didactical design research provide through a zoom meeting, and it will continue with the creation and development of a didactic design for learning mathematics based on the problems faced by the teacher. After the participants' activities, especially teachers, based on the results of the questionnaire response analysis of knowledge and understanding related to the concept of didactical design research, then the practice of reflection based on didactical design research increases and is ready for a workshop.
\end{abstract}

Keywords: reflection practice, didactical design research, junior high school mathematics teachers

\section{A. Introduction}

The educational process must accommodate the needs of human individuals to have readiness in facing a new era. National Education has a goal stated in the Law of the Republic of Indonesia Number 20 of 2003, which is to develop capabilities and shape the character and civilization of a dignified nation in the context of the nation's intellectual life and improve existing capabilities.
The primary competence of teachers is the construction of aspects of knowledge and skills (Blömeke et al., 2020). The essence of learning mathematics is not only to master mathematical concepts but to provide an operational experience of mathematical thinking (Suryadi, 2018). So to support this, it is necessary for teachers who have good knowledge of mathematical material. Solid material knowledge in mathematics is an 
essential component for teachers (Suryadi, 2018). So to support this, it is necessary for teachers who have good knowledge of mathematical material. Solid material knowledge in mathematics is an essential component for teachers (Güler et al., 2020). Teacher competencies that are consistently maintained will ensure that educational goals can be appropriately achieved (Lasauskien et al., 2015).

Teacher competence plays an essential role in realizing quality education. Therefore, the Indonesian Government has set four competency standards that teachers must possess. Law Number 14 of 2005 concerning Teachers and Lecturers needs to have pedagogic, professional, personal, and social competencies. While becoming a teacher maintains four competencies, these four qualities are also prerequisites and references in teacher recruitment and professional development. The full description of the four competencies is contained in the Regulation of the Minister of National Education No. 16 of 2007 concerning teacher competency standards.
Professional teachers' primary responsibility is to carry out teaching and learning responsibilities in the classroom and be accountable for longterm professional development. Teacher professional development is a process that occurs spontaneously or as a result of deliberate and planned activities that help to improve the quality of learning (Day, 2002) that the Government realizes the importance of continuous professional development of teachers with the issuance of the 2009 Regulation of the Minister of Administrative and Bureaucratic Reform which places sustainable professional development as the main component of teacher career development.

The practice of reflection is a form of teacher professional development activity that has become the focus of study, research, and discussion in several scientific forums. In addition, several teacher professional development programs in several countries make reflection one of the models. This teacher, the professional development model, can link learning theory and practice to affect the quality of learning directly. 
In 2009, through the assistance of the World Bank and the Government of the Netherlands, the Ministry of National Education programmed BERMUTU, one of its programs for teacher professional development through reflective practice in the Teacher Working Group (KKG) Subject Teacher Consultation (MGMP) communities. Through this program, the Government provides direct grants to the KKG and MGMP communities to carry out classroom action researchbased reflection practices. This program only facilitates elementary and junior high school levels. At the junior high school level, Mathematics is one of the subjects given direct funding facilities.

Several studies have examined several approaches in the practice of collaborative mathematics teacher professional development. The model approach to the practice of developing mathematics teachers, namely: lesson study, educational action research, teaching research groups, educational design research, and learning study (Holmqvist, 2017). DDR is educational design research. DDR for mathematics teachers developed in Indonesia, both at the elementary, junior high, and high school levels. So far, DDR is used to improve the learning process based on student responses, as has been done by Setiadi et al. (2017), Haqq et al. (2018)(Fauzi \& Suryadi, 2020) Fatimah et al. (2018). However, none of these studies has examined how DDR as a reflective practice approach in increasing the knowledge of pedagogic content of mathematics teachers.

This learning reflection practice is expected to be a source or reference for mathematics teachers in their professional development. In addition, the results of this study are expected to be valuable information for the Government, especially the Ministry of Education and Culture, in formulating a mathematics teacher professional development program. The results of this study are also expected to be valuable findings as an alternative educational research model that is a requirement for teachers in their career development.

Based on this, it is hoped that by using reflective practice in DDR, mathematics teachers can develop teacher professional competencies, 
namely pedagogic, professional, personality, and social competencies.

The Teacher Working Group $(\mathrm{KKG})$ in the Educational UPTD of Talaga District and Cingambul District of Majalengka Regency is an education UPTD located in the southern region of Kab. Majalengka, which is directly adjacent to Kab. Ciamis has many teacher members, but the learning reflection process carried out by the Teacher Working Group (KKG) has not been going well. It is still necessary to improve the learning reflection process and method used.

Teachers' understanding of learning mathematics in the classroom needs to be strengthened that learning mathematics is an individual's thought process to accept a change. The method of learning mathematics has a role in shaping a student's mindset in seeing the problems he faces. By learning mathematics, it is expected that students can develop all their abilities ranging from understanding skills, communication skills, reasoning skills, problem-solving, critical and creative thinking.

However, in reality, the mathematics subject for most students at the elementary school level is still terrifying because of their difficulty understanding the concepts of the material taught by the teacher. Thus, the teacher is responsible as an educator who must slowly eliminate the scary and challenging impression when learning mathematics by most of his students.

The problems found in the preliminary study in the UPTD Pendidikan Talaga District and Cingambul District in the field indicate that when teaching, teachers tend to use mechanical methods, namely giving direct rules to be memorized. In implementing the learning process, the teacher still relies on existing sourcebooks without considering student responses. This allows for learning barriers for students and impacts the lack of didactic anticipation, which is reflected in the preparation made by the teacher.

So we can conclude that the lesson plans that usually do not consider the diversity of student responses to the developed didactic situations cause the series of didactic situations that are designed that are most likely no longer 
following the variety of each student's learning trajectory.

Based on this, the teacher as a facilitator in the learning process should design an appropriate didactic design to be applied, following the student's condition and the student's environmental situation.

Therefore, this Community Service activity is intended to provide an alternative reflection of learning carried out by teachers, especially elementary school teachers in the UPTD Pendidikan Talaga District and Cingambul District. The reflection practice used is based on DDR. Therefore, this community dedication will focus on the Workshop on the implementation of Didactical Design Research (DDR) as a learning reflection process carried out by teachers in the Teacher Working Group (KKG) community in the UPTD Pendidikan, Talaga District, and Cingambul District. So that community dedication activities are expected to assist teachers in implementing learning reflection based on DDR, DDR is research that uncovers learning obstacles in the learning process and aims to anticipate and eliminate learning barriers in learning .

\section{B. Method of Implementation}

This community service begins with an introduction to the DDR form and its characteristics, continued with the creation and development of a didactic design for learning mathematics based on the problems faced by each teacher. As a follow-up, assistance was provided in implementing the designed didactic design and then evaluation and reflection. The flow of the implementation of the teacher reflection practice process based on the DDR for the Teacher Working Group in Cingambul and Talaga Districts is as follows (figure 1) :

The following is a description of the activities of the service team and teachers who are members of the Teacher Working Group in the Talaga and Cingambul sub-districts based on the flow of the implementation of community service activities in the Practice of Reflecting Learning Based on DDR (Didactical Design Research) as follows: 


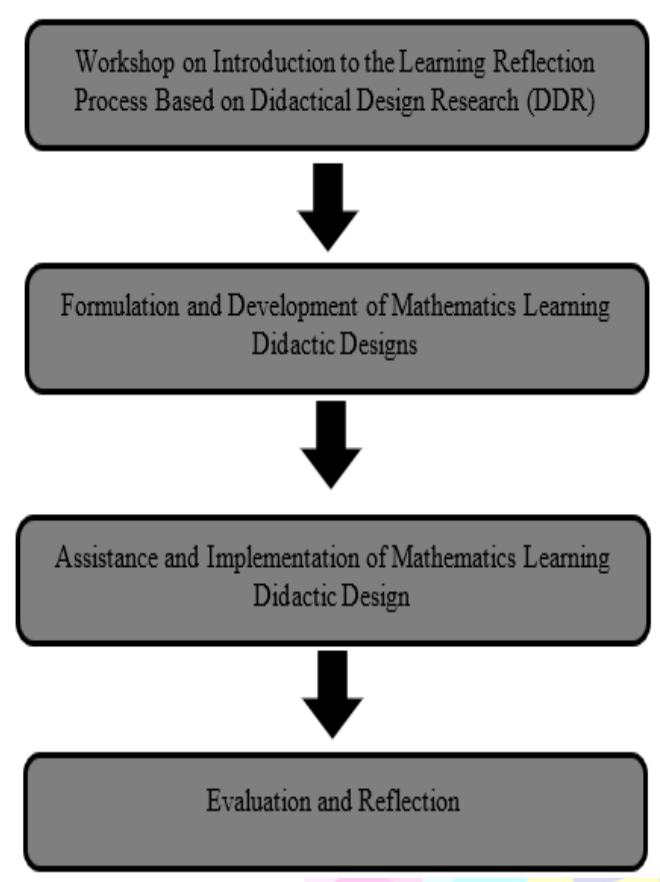

Figure 1. Program Implementation Method

1. Workshop on Introduction to Learning Reflection Based on Didactical Design Research (DDR).

The first activity that was carried out was the socialization of the Workshop which was held in the PGRI UPTD Education building, Talaga District, and Cingambul District - then continued with the provision of material on the practice of ReflectionBased Learning Based on Didactical Design Research (DDR). The material condition refers to the theory developed by (Suryadi, 2019). The proper steps of didactical design research (DDR) consist of three stages:
1). Didactic situation analysis before learning (prospective analysis) in a Hypothetical Didactic Design including ADP, 2). Metapedadidactic analysis, and 3). Retrospective analysis is an analysis that links the hypothetical didactic situation analysis results with the metapedadidactic analysis results. KKG Community teachers in Talaga District and Cingambul District. The teachers attended the Workshop held at the PGRI Building in the two KKG communities, Kec. Talaga and Kec. Cingambul begins with the socialization process of the Community Partnership Program, followed by material on the practice of learning reflection based on Didactical Design Research (DDR). Then in the workshop activities, the teacher implements several activities. Namely, the teacher is asked to do thinking activities before learning, emphasizing the teacher's actions in designing didactic situations that will be carried out in the learning process, including recontestualization and between personalization, and response prediction. Then the teacher is directed to try to think during the learning process, also to emphasizing 
metapedadidaktik analysis of didactic situations, student responses, and analysis of interactions that impact changes in didactic conditions during learning at the post-learning stage. Finally, the teacher is asked to reflect on the learning process related to what has been planned. After being given an example of the practice of learning reflection based on Didactical Design Research (DDR), at the end of the activity, participants are expected to be able to determine the material that will be made a didactic design to be developed and then implemented then the teacher. Next, the service team conducts evaluation and reflection.

2. Preparation and Development of Mathematics Learning Didactic Design.

Provide modules and guide the preparation and development of a didactic design for mathematics learning where formally the implementation of the practice begins with:

a. Analysis of the didactic situation before learning in the form of a hypothetical didactic design including ADP.

b. Metapedadidactic analysis. c. Retrospective analysis is an analysis that links the hypothetical didactic situation analysis results with the metapedadidactic analysis results.

This PKM activity will be carried out in 3 meetings. The proper steps above can then be described in several stages of Service as follows:

Stage 1: Prospective Analysis

1) Choose math material used as material in implementing activities based on students' difficulties in learning mathematics.

2) Looking for some literature references about the selected material.

3) Study and analyze the material that has been selected, including characteristics, the flow of material, teaching models that may be suitable for use.

4) Develop test instruments to identify learning obstacles related to the selected concepts.

5) Testing the test instruments that have been made to several students.

6) Conducted interviews with several respondents regarding the instruments given. 
7) Analyzing data from instrument test results and interviews conducted.

8) Make conclusions about the learning obstacles obtained from the results of testing the test instruments associated with existing learning theories.

9) Develop a related hypothetical learning trajectory that has been selected.

10) Develop a didactic design based on a hypothetical learning trajectory and learning obstacle findings and relate it to relevant learning theories.

11) Make predictions about student responses that may arise when the didactic design is applied and prepare to anticipate student responses.

Stage 2: Metapedadidactic analysis

1) Implement a didactic design.

2) Metapedactic analysis, namely the analysis of the didactic situation based on various student responses when the didactic design was implemented.

Stage 3: Retrospective Analysis

1) Linking response predictions and anticipations that have been made before learning is carried out with student responses during the implementation of the didactic design.

2) Conducting a learning obstacle test.

3) Develop a revised didactic design based on implementing the didactic design and analysis of the learning obstacle test results after implementing the didactic design.

4) Prepare reports on implementation results.

KKG Community Teachers in Talaga District and Cingambul. District accompanied by a team of teacher companions, make and develop a didactic design based on the learning obstacle in learning mathematics following the material selected by the teacher based on the results of the previous analysis.

3. Assistance and Implementation of Mathematics Learning Didactic Design

The didactic design for learning mathematics that has been made is implemented in classroom learning at each school. During learning, teachers are accompanied by a service team. At the end of the lesson, the service team 
and the teacher evaluate the implementation of the didactic design for learning mathematics in the classroom.

KKG Community Teachers in Talaga and Cingambul Districts Implement the learning process due to the practice of reflection based on Didactical Design Research (DDR) that has been made.

\section{Evaluation and Reflection}

At this stage, an evaluation of the learning outcomes of the practice of learning reflection based on Didactical Design Research (DDR) is carried out, which is implemented in the learning process in the classroom. This activity also reviewed all the activities that have been carried out. The examination begins with filling out questionnaires, questions and answers, and discussions with the teacher as material for consideration or recommendations for further activities.

\section{Result and Discussion}

The community service program with the title "Didactical Design Research-Based Reflection Practice in Teacher Professional Development" has been going well. The Service will be held on June 5, 2021, online through the Zoom Meeting facility. The service activities were attended by 96 people from various professions such as teachers, lecturers, and students. The implementation of online Service is carried out to provide in-depth knowledge related to the concept of Didactical Design Research and its implementation in the practice of teacher reflection. The implementation of service activities invites three main speakers, who have different roles when delivering the material.

The first speaker is Dr. H. Sufyani Prabawanto, M.Ed, a lecturer in Didactical Design Research and is part of the Indonesian Didactical Design Research Center. In-service activities providing knowledge related to strengthening the concept of didactical design research, below are some examples of material presented by the first speaker;

Apakah DDR dapat berperan dalam praktik refleksi?

Secara filosofis DDR mengacu pada dua paradigma riset: PARADIGMA INTERPRETIF dan PARADIGMA KRITIS

DDR dikembangkan dengan beberapa alasan, antara lain melakukan pergeseran dari: (1) siswa menerima pengetahuan menjadi memaknai, membangun, dan menggunakan pengetahuan; (2) Guru sebagai pengembang pengetahuan 
Figure 1. DDR Concept PowerPoint

Slides

DDR itu apa?

Didactic $=$ the Art of Education

Design = Rancangan atau Perancangan

Research = Pencarian atau pengkonstruksian pengetahuan baru

Belajar serupa dengan riset

Pengetahuan = Justified True Belief

Figure 2. DDR Concept PowerPoint Slides

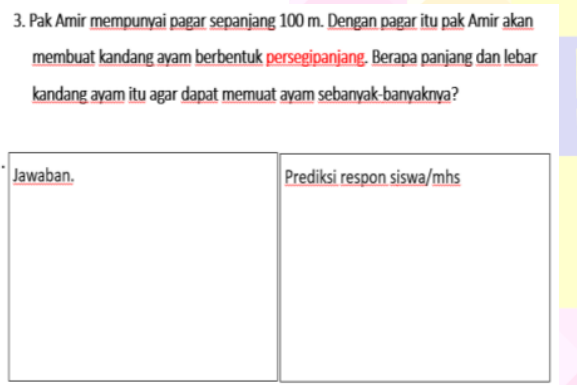

Figure 3. PowerPoint Slides Examples of Reflection Materials

The second material was delivered by Dr. Rudi, M.Si, a Widyaiswara from LPMP South Sulawesi Province. The focus of providing the material is related to the practice of DDR-based reflection on teachers. Some examples of the material presented are;

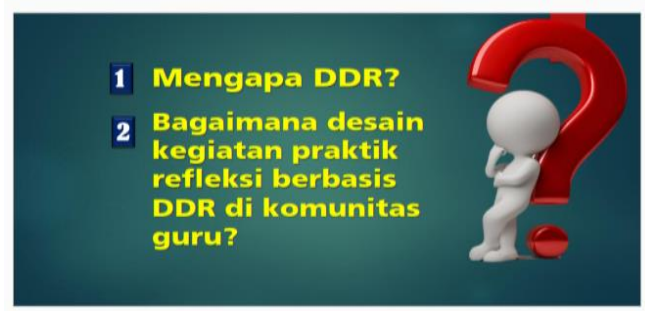

Figure 4. DDR PowerPoint Slides and Reflection Practice

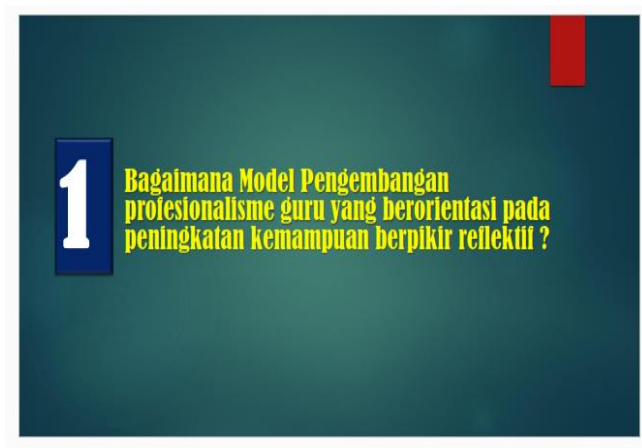

Figure 5. DDR PowerPoint Slides and Reflection Practice

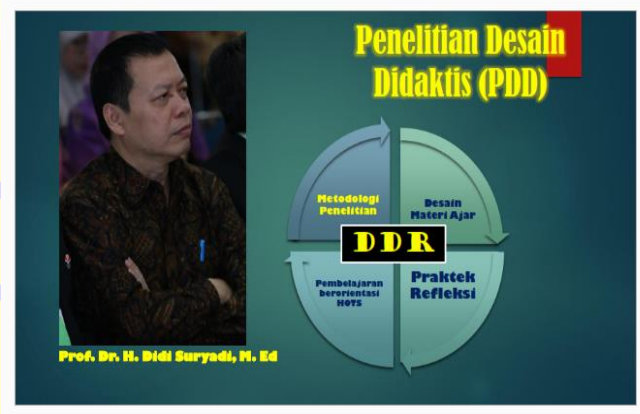

Figure 6. DDR PowerPoint Slides and Reflection Practice

The third speaker is a junior high school teacher in the Majalengka district who has experience conducting DDR research. As for some of the material presented by the third speaker, namely:

\section{Latar Belakang}

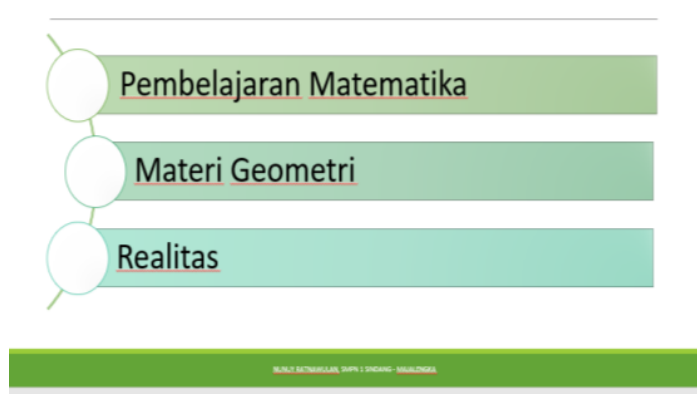

Figure 6. DDR PowerPoint Slides By Teacher 


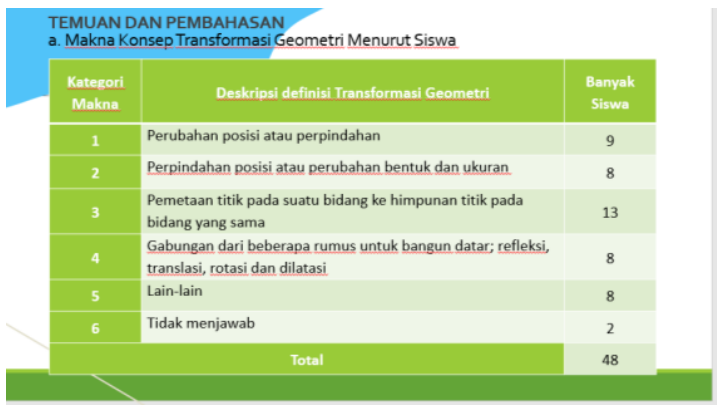

Figure 6. DDR PowerPoint Slides By Teacher

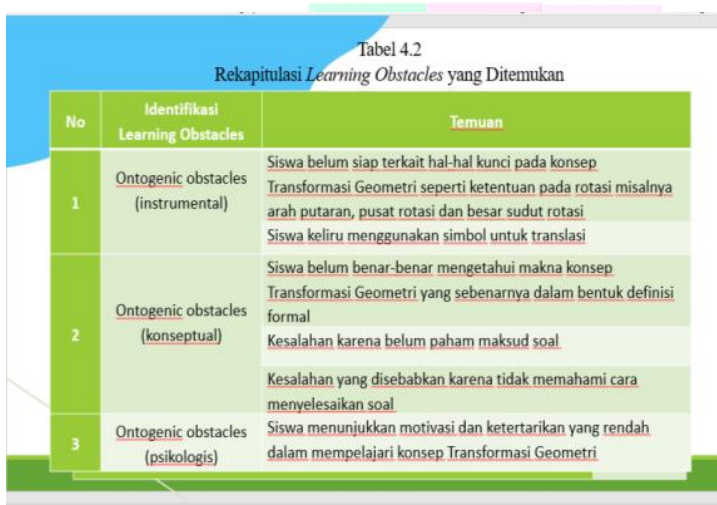

Figure 6. DDR PowerPoint Slides By Teacher

In general, the implementation of this community service activity went well. This can be seen from the responses given by the participants. Therefore, the committee was satisfied with the performance of this service activity. After completing the service process, an evaluation is carried out through a questionnaire filled out online. The conclusions of the questions answered can be described as.

Analysis of participant responses related to providing student information dominates the service

\section{PROFESI}

96 jawaban
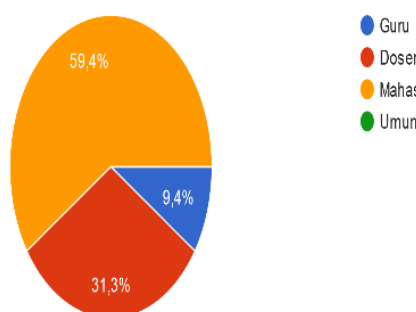

Dosen

Mahasiswa

- Umum

Figure 7. Participants' Responses by Profession

activities carried out, although the initial concept design of this event was specifically for teachers. This informs us that the public's response to the practice of reflection based on didactical design research will become an interesting issue as a study material in mathematics education.
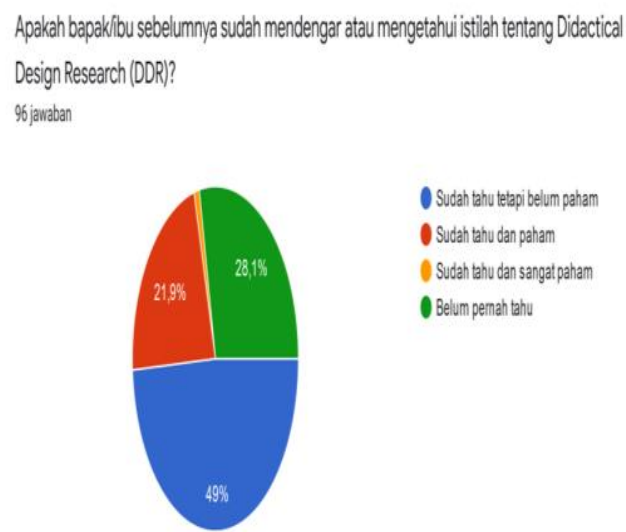

OSudah tahu teapi belum paham Sudah tahu dan paham OSudah tahu dan sangat paham Belum pernah tahu

Figure 8. Responses of Participants' Understanding of DDR

Participants' responses provided information that most of the practice of reflection based on didactical design research did not know. The analysis of this response clarifies what happened 
to the previous response related to the profession that participated in service activities.

Apakah bapakkibu sebelumnya pernah melakukan praktik refleksi berbasis Didactical Design Research (DDR) pada KBM di kelas?

95jawdaban

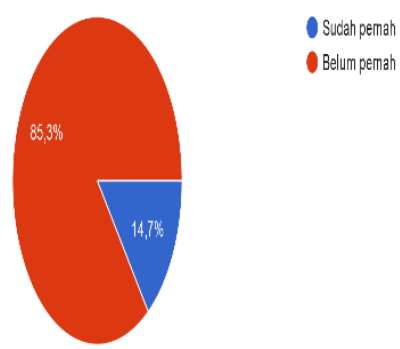

Figure 9. Responses of Participants' Understanding of DDR-based Reflection Practices

Analysis of participants' understanding provides information to the committee team. The participants could well understand the material related to the DDR-based Reflection Practice concept given by the speaker.

Bagaimana pengetahuan bapakilbu setelah mengikuti kegiatan webinar ini? 96jawaban

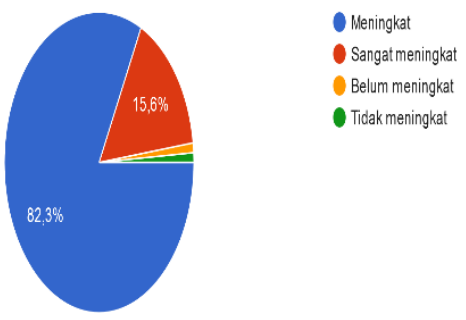

Figure 10. Participants' Knowledge

Response regarding the implementation of Service

Analysis of participants' knowledge provides information to the committee team that the participants can well accept the command given by the presenter.

The primary purpose of this service activity is to deepen knowledge related to the professional development of teachers. This service activity is divided into two series. The first series with expert speakers in DDR and Reflection Practice. The second series of special workshops with particular junior high school teachers. The response above informed us that the participants were ready for a DDRbased Reflection Practice workshop.

\section{Conclusion}

Based on the results of the questionnaire analysis of the activities in general, implementing community service activities went well and impacted providing knowledge and understanding of the concept of didactical design research (DDR). This knowledge and understanding is a provision for us as a committee to carry out more practical workshops with teachers in Majalengka Regency.

\section{REFERENCES}

Hodgson, J., \& Weil, J. (2011). Commentary: How individual and profession-level factors influence discussion of 
disability in prenatal genetic counseling. Journal of Genetic Counseling, 1-3.

Blömeke, S., Kaiser, G., König, J., \& Jentsch, A. (2020). Profiles of mathematics teachers' competence and their relation to instructional quality. ZDM, 1-14. https://doi.org/10.1007/s11858020-01128-y

Day, C. (2002). Developing teachers: The challenges of lifelong learning. Routledge.

Fatimah, I., Hendayana, S., \& Supriatna, A. (2018). Didactical design based on sharing and jumping tasks for senior high school chemistry learning. Journal of Physics: Conference Series, 1013(1), 12094.

Fauzi, I., \& Suryadi, D. (2020). Didactical Design Research untuk Mengembangkan Kompetensi Pedagogik Guru di Sekolah Dasar. INVENTA: Jurnal Pendidikan Guru Sekolah Dasar, 4(1), 58-68.

Güler, M., Çekmez, E., \& Çelik, D. (2020). Breaking with tradition: An investigation of an alternative instructional sequence designed to improve prospective teachers' noticing skills. Teaching and Teacher Education, 92, 103073.

Haqq, A. A., Nasihah, D., \& Muchyidin, A. (2018). Desain Didaktis Materi Lingkaran Pada Madrasah Tsanawiyah. Eduma: Mathematics Education Learning and Teaching, 7(1), 71-82. https://doi.org/10.24235/eduma.v $7 \mathrm{i} 1.2731$

Holmqvist, M. (2017). Models for collaborative professional development for teachers in mathematics. International Journal for Lesson and Learning Studies.

https://www.emerald.com/insight /content/doi/10.1108/IJLLS-12-

2016-

0051/full/html?casa_token $=$ Kdks

Wz4jc2kAAAAA:a2HYqRriOvk 1Ef0n69WOC9jTTWjrKINhIiCV ucAnnbQvA8oUaJllc1BrmcpO7h lztt2lrdapNXnA1ZkRV33nrGaSNFhKP2JzfQscJ1Xf0dNsC5_7h $\mathrm{Y}$

Lasauskien, J., Rauduvait, A., \& Barkauskait, M. (2015). Development of general competencies within the context of teacher training. ProcediaSocial and Behavioral Sciences, 191, 777-782.

Setiadi, D. R., Suryadi, D., \& Mulyana, E. (2017). Didactical Design Enrichment of Angle in Geometry. Journal of Physics: Conference Series, 895(1), 12060.

Suryadi, D. (2018). Ontologi dan epistemologi dalam penelitian desain didaktis (DDR). Bandung: Departemen Pendidikan Matematika Universitas Pendidikan Indonesia.

Suryadi, D. (2019). Landasan Filosofis Penelitian Desain Didaktis (DDR). https://doi.org/10.1080/10511979 808965910 